Original Research

\title{
The Effects of Tillage-Induced Soil Disturbance on Soil Quality
}

\author{
Igor Dekemati ${ }^{1}$, Igor Bogunovic ${ }^{2}$, Ivica Kisic ${ }^{2}$, Zoltán Radics ${ }^{1}$, \\ András Szemők ${ }^{1}$, Márta Birkás ${ }^{1 *}$ \\ ${ }^{1}$ Institute of Crop Production, Szent István University, Gödöllő, Hungary \\ ${ }^{2}$ Department of General Agronomy, University of Zagreb, Zagreb, Croatia
}

Received: 9 July 2018

Accepted: 7 October 2018

\begin{abstract}
The aim of this paper was to investigate the tillage-induced changes in soils in 2010-2017, and rank tillage management in the present climate situation. The study was carried out on Chernozems, where five ploughless tillage treatments - loosening (L), tine tillage (a deeper T, and a shallower, ST), disk tillage (D) and direct drilling (DD) - were compared with ploughing (P). Soil condition was evaluated in accordance with the crumb ratio, the soil moisture range for workability, the extension of compacted tillage pan, the crust formation and number of earthworms. The higher ratio of crumbs was found at the treatments where cover ratio reached at least $20 \%$ after sowing (at T, ST, and DD). Significant differences were found between soil moisture ranges for the workability of different tillage operations $(\mathrm{p}<0.05)$. The $\mathrm{T}$ treatment proved to be an adaptable solution to the extreme soil moisture contents. Extension of the compacted pan was moderated under ST, T and L. The crust occurrence was lower under ST, T and DD with residue cover. DD, ST and T had a significantly higher number of earthworms compared to other treatments. Soil condition ranking revealed the suitability of the tillage managements for alleviating the farming and the climate hazards.
\end{abstract}

Keywords: crumb, soil workability, pan compaction, crusting, earthworm number

\section{Introduction}

Specification of the tillage trends (conventional, reduced, conservation etc.) and endeavours (e.g., energy saving, sustainable) has been made possible in the last 50-60 years. Soil protection has become the main requirement in the soil conservation trend contributing to the implementation of the long-term defence strategy [1]. In the relevant experiments, control often involves

*e-mail: Birkas.Marta@mkk.szie.hu conventional tillage as a treatment with negative impact on soil compared with treatments that present a possible solution as direct drilling, mulch-till, etc. [2]. Nowadays soil tillage aim has been changed. The minimal soil disturbance may be replaced with soil intervention to the required extent that is reinforced by the use of several protection techniques, e.g., surface cover, surface layer consolidation, loosened layer adaptable to the water conservation and organic matter protection.

Today, soil health evaluates compliance of the tillage systems and appropriate factors are applied that could be evaluated anywhere: crumb ratio, soil moisture range 
for workability, extension of the tillage pan compaction, crust formation and the level of earthworm habitat.

The crumb ratio of soil and the level of the crumbling may be used to evaluate soil tillage impact on soil quality [3]. Morris et al. [4] found that crumb formation is falling both in dry and wet conditions. Kalmár et al. [5] outlined that breakdown of the crumbs leads to the displacement of small soil particles forming a more continuous structure (mud film), which creates a surface seal and, later, a surface crust.

Adaptation to the moisture range suitable for cultivation can become more important in avoiding climate-induced damage [6]. In the present climate situation, instead of the optimal soil moisture for workability, the suitable solution for an extreme situation can be taken into account [7]. The extension of tillageinduced soil compaction is a great threat in the wet seasons and that will become a limiting factor for water movement in the following season [8, 9]. GallardoCarrera et al. [10] confirmed that surface crusting is considered an important factor during sowing and seed emergence. However, hardly any attention has been paid to the same during the rest of the growing season or after wintering between rows of crops and in the surface of cultivated soils. Although earthworm numbers in soil have became an important soil quality indicator, the authors underline that the activity of earthworms is influenced by several factors $[11,12]$. The two extremes of the climate - too wet or too dry conditions in the soil - require applying a cultivation method causing minimal damage to soils. This concept is quite new in the southeast European soil cultivation practice [13-15].

Few of the papers mentioned [6, 13, 14] have answered the primary question of soil tillage role in the regional climate damage mitigation solutions. Considering this, the aim of this paper was to investigate the tillage and climate-induced changes on soil quality factors and rank soil condition, on a scale of the best to the worst in the present climate situation.

\section{Material and Methods}

\section{Site Description}

A long-term tillage experiment was initiated at the Experimental and Training Farm of Szent István University near the town Hatvan $\left(47^{\circ} 68^{\prime} \mathrm{N}, 1^{\circ} 60^{\prime} \mathrm{E}\right.$, $110 \mathrm{~m}$ a.s.l) in 2002. The terrain is flat, with a soil of a clay-loam texture, Endocalcic Chernozems, Loamic [16], a humus content of $3.12 \%$ (in 2015); the sand, silt and clay contents of the top $20 \mathrm{~cm}$ layer are $10 \%$, $54 \%$ and $36 \%$, respectively [17]. The precipitation amounts were measured at the weather station of the Training Farm. Although the multi-year average of the precipitation is $580 \mathrm{~mm}$, the distribution has been rather extreme. The precipitation figures in the last eight years were as follows: dry (2011, 2012), rainy (2010, 2014, 2016) and changeable $(2013,2015,2017)$. The amount of precipitation in the last eight years is represented in Fig. 1.

\section{Experimental Design}

The one-factorial experiment was arranged in a randomised block design with four replicates. Plot size was $13 \times 185 \mathrm{~m}$. Five ploughless tillage treatments (loosening, 0.4-0.45 m, L), tine tillage (a deeper, 0.22-0.25 m, T, and a shallower, 0.18-0.22 m, ST), disk tillage (0.12-0.16 $\mathrm{m}, \mathrm{D})$ and direct drilling (DD) were compared with mouldboard ploughing (0.30-0.34 m, P). Primary tillage was applied in accordance with soil workability, except for two autumnal wet seasons (in 2015 and 2016). Primary and secondary soil tillage was carried out in a single pass for cereals, and seedbed preparation applied for widerow crops only.

Crop sequence was planned for soil quality improvement and suppression of the weeds. Crops that were sown in the last eight years are: maize (2010), oat (2011), winter wheat (2011/12), spring barley (2013),

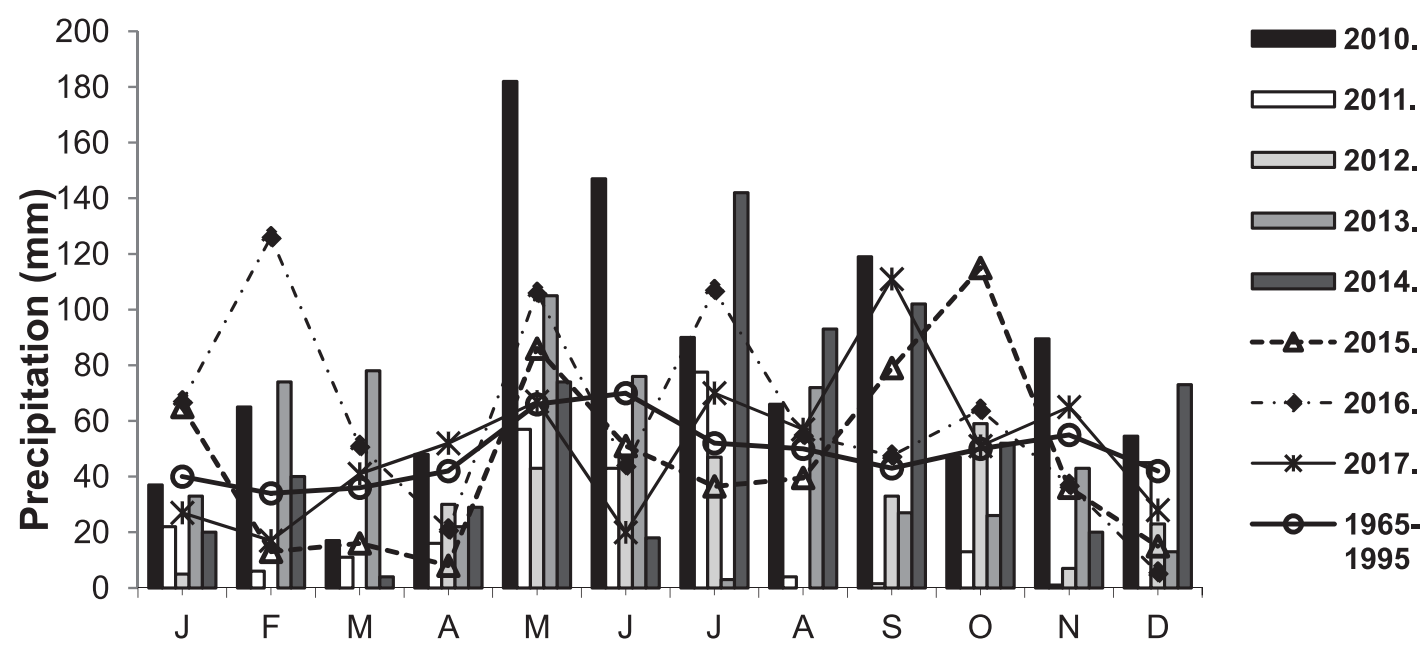

Fig. 1. Monthly cumulative precipitation amounts (mm) for eight experimental years and the 30-year period (1965-1995). 
Table 1. Average surface cover ratio after sowing (\%).

\begin{tabular}{|c|c|c|c|c|c|c|}
\hline \multirow{2}{*}{ Crop residues } & \multicolumn{6}{|c|}{ Tillage treatments } \\
\cline { 2 - 7 } & $\mathrm{L}$ & $\mathrm{P}$ & $\mathrm{T}$ & $\mathrm{ST}$ & $\mathrm{D}$ & $\mathrm{DD}$ \\
\hline Cereals and maize & 30.0 & 0 & 35.0 & 37.5 & 12.5 & 40.5 \\
\hline Sunflower & 12.5 & 0 & 15.0 & 17.5 & 7.5 & 20.5 \\
\hline
\end{tabular}

Note: L: loosening, P: ploughing, T, ST: tine tillage, D: disk tillage, DD: direct drilling.

sunflower (2014), winter wheat (2014/15), maize (2016) and winter oat (2016/17).

Crop residues were chopped and spread in the single pass of the harvest. The cover ratio of stubble residues after sowing is presented in Table 1. Post-emergence herbicide was used in the spring. A direct chemical treatment was applied in five years (2011, 2012, 2013, 2015 and 2017) on cereal stubbles at the end of August.

\section{Soil Condition Assessment}

Samples to check soil condition and moisture content were taken in 30-day intervals in each treatment in five repetitions. Crumbs in the Hungarian soil physics categorisation system [18] are defined as soil aggregates ranging from 0.25 to $10 \mathrm{~mm}$ in diameter, of which those falling in the range of $0.25-2.5 \mathrm{~mm}$ qualify as small crumbs and $<0.25 \mathrm{~mm}$ as dust. Sampling was carried out to the depth of $0-100 \mathrm{~mm}$ as for this is mostly exposed to the climate damages. The soil samples were air-dried and then gently sieved manually (60 shakes/min). The mass distribution between the grades was also established.

Soil moisture measurements were taken with the PT-I type gauge (Kapacitiv Kft, Budapest, Hungary). The LCD display of the instrument shows the moisture content in terms of percentage or $\mathrm{g} \mathrm{g}^{-1}$. The soil is categorised as dry, humid or wet when its moisture content ranges between 14.8-18.9, 19.0-23.9, or $>24.0 \%, \mathrm{~g} \mathrm{~g}^{-1}$, respectively [19].

Soil moisture ranges for workability were selected from data obtained in the different seasons [20]. Six categories were stated to meet the requirements of the workability: workability lower level (WL), workability highest level (WH), optimal water content for subsoiling (OS), optimal water content for ploughing (OP), optimal water content for tillage (OT) and highest water content for tine tillage (HT).

Occurrence and extension of the compacted pan in soils was measured by penetrometers using a handheld Szarvas-type penetrometer (Mobitech, Hungary) with a $10.0 \mathrm{~mm}$ diameter cone and a $60^{\circ}$ apex, at soil depths of $0.55 \mathrm{~m}$ at each $0.05 \mathrm{~m}$ increment, in at least five repetitions. The tip of the probe penetrated the soil at a standard speed of $20 \mathrm{~mm} \mathrm{sec}^{-1}$. The force meter's scale is calibrated for $150 \mathrm{lbf}$, at $2 \mathrm{lbf}$ intervals. Multiplying the readings by 0.04448 yields the soil's resistance value in MPa. At the same time soil moisture content was measured at each treatment. The cover ratio of crust was measured with a quadrate device with an area of $0.25 \times 0.25 \mathrm{~m}$. Earthworms were collected from the unit area $\left(1 \mathrm{~m}^{2}\right)$ to the depth of $0-200 \mathrm{~mm}$ after excavating and screening a certain volume of soil. Visual soil state monitoring was also an important additional activity to verify the measuring data by instruments, e.g., measuring the distribution of stubble residues in the tilled layer, occurrence and extension of the compacted pan.

\section{Tillage Systems Ranking}

In the framework of the experiment, the impact of soil tillage systems was rated on a scale of the best to the worst following ideas as described Sallaway et al. [21]. Details of the ranking were redesigned to cover the aims of the present study. The cultivation systems were ranked according to six criteria. Scoring the ranked position in first place is worth 5 , second 4 , third 3, fourth 2 , fifth 1 , and the very last 0 . Finally, in the best case 30 points and in the worst case 0 points could be summed.

\section{Statistical Analyses}

The tillage impact on four soil quality factors was studied by measuring changes in the crumb ratios, the soil moisture content for workability, the extension of pan compaction and the crust formation. The differences between the treatments and the responses of soil factors were determined by one-way ANOVA using Microsoft Excel 2016 software (Szent István University, Hungary). The least significant difference (LSD) at a significance level of $p<0.05$ was used to identify differences between treatment means and was completed using Fisher's adjustment [22]. For evaluating the effect of the tillage on soil-crumb ratio we used a linear regression analysis [22]. The data used in the analysis are also examined to indicate the range of variables. Correlations between the individual data were controlled using Microsoft Excel 2016 software (Szent István University). The relationships between two factors, i.e., ratio of total and large crumbs, was examined by the way of rank correlation [22]. The rank correlation coefficient measured the degree between two rankings and examined the significance $(\mathrm{p}<0.05)$ of the relationship between them.

\section{Results and Discussion}

\section{Changes in Soil Crumb Ratio}

The total ratio of total crumbs in the upper $100 \mathrm{~mm}$ layer for six tillage treatments varied between 61 and 88 in the given eight years (Table 2). This result is consistent with Stefanovits [23], who indicated that 
Table 2. Total crumb $(0.25-10 \mathrm{~mm})$ percentage in unit mass at different soil tillage and in variable seasons.

\begin{tabular}{|c|c|c|c|c|c|c|c|c|c|}
\hline \multirow{2}{*}{ Year } & \multirow{2}{*}{ Crop } & \multicolumn{9}{|c|}{ Tillage treatments } & \multirow{2}{*}{ Sum } & \multirow{2}{*}{ Mean } \\
\cline { 3 - 9 } & & $\mathrm{L}$ & $\mathrm{P}$ & $\mathrm{T}$ & $\mathrm{ST}$ & $\mathrm{D}$ & $\mathrm{DD}$ & & \\
\hline 2010R & Maize & 72 & 70 & 77 & 77 & 74 & 73 & 443 & 73.9 \\
\hline 2011D & Spring oat & 63 & 64 & 69 & 63 & 65 & 62 & 386 & 64.5 \\
\hline 2012D & Winter wheat & 84 & 78 & 86 & 85 & 82 & 88 & 503 & 83.9 \\
\hline 2013RD & Spring barley & 82 & 79 & 85 & 85 & 80 & 80 & 491 & 81.7 \\
\hline 2014R & Sunflower & 76 & 70 & 80 & 81 & 69 & 77 & 453 & 75.4 \\
\hline 2015DR & Winter wheat & 82 & 75 & 87 & 88 & 76 & 84 & 492 & 82.0 \\
\hline 2016R & Maize & 70 & 61 & 79 & 80 & 62 & 72 & 424 & 70.8 \\
\hline 2017DR & Winter oat & 72 & 63 & 81 & 83 & 61 & 66 & 426 & 71.0 \\
\hline Sum & & 601 & 560 & 644 & 642 & 569 & 602 & 3618 & \\
\hline Mean & & $75.1 \mathrm{~b}$ & $70.0 \mathrm{c}$ & $80.5 \mathrm{a}$ & $80.3 \mathrm{a}$ & $71.1 \mathrm{bc}$ & $75.3 \mathrm{ab}$ & & \\
\hline
\end{tabular}

Note: R: rainy, D: dry, RD: rainy and dry, DR: dry and rainy, L: loosening, P: ploughing, T, ST: tine tillage, D: disk tillage, DD: direct drilling. Means followed by similar letters are not significantly different as statistically $(\mathrm{p}<0.05)$.

the crumb ratio in a soil is favourable when it reaches or surpasses $70 \%$ in a unit mass.

The tillage treatments through soil disturbance had a significant impact on total soil crumb ratio $(\mathrm{p}<0.05$; Tables 2-3). The crumb formation remained moderate in one rainy season (2010) and dropped by $13 \%$ in the next dry year (2011). The highest ratio of total crumb occurred during 2012, 2013 and 2015, and may be due to

Table 3. Analysis of variance, degrees of freedom and significance levels for soil quality factors.

\begin{tabular}{|c|c|c|c|}
\hline Sources of variance & $d f$ & $F$ & $\mathrm{LSD}_{0.05}$ \\
\hline Total crumb $\%$ & 5 & $10.68 * * *$ & 5.06 \\
\hline Large crumb\% & 5 & $13.50 * * *$ & 3.30 \\
\hline $\begin{array}{l}\text { Rank correlation for average } \\
\text { year }\end{array}$ & 5 & 0.4290 & ns \\
\hline Rank correlation for dry years & 5 & 0.7143 & ns \\
\hline Rank correlation for wet years & 5 & 0.9146 & $* *$ \\
\hline $\begin{array}{l}\text { Soil moisture }\left(\mathrm{g} \mathrm{g}^{-1}\right) \\
\text { for workability }\end{array}$ & 5 & $4.76^{* * *}$ & 5.79 \\
\hline Plough pan (mm) in 2002 & 4 & $27.544 * * *$ & 2.12 \\
\hline Plough pan (mm) in 2017 & 4 & $996.8 * * *$ & 4.31 \\
\hline $\begin{array}{c}\text { Crusted area }(\%) \text { in different } \\
\text { years }\end{array}$ & 5 & $6.86^{* *}$ & 15.2 \\
\hline $\begin{array}{c}\text { Crusted area }(\%) \text { in rainy } \\
\text { seasons }\end{array}$ & 5 & $257.887 * * *$ & 3.30 \\
\hline Crusted area (\%) in dry seasons & 5 & $192.636^{* * *}$ & 0.81 \\
\hline $\begin{array}{c}\text { Crusted area }(\%) \text { in average } \\
\text { seasons }\end{array}$ & 5 & $7.88 * * *$ & 2.27 \\
\hline $\begin{array}{l}\text { Earthworm number } \\
\left(1 \mathrm{~m}^{2}, 0-200 \mathrm{~mm}\right)\end{array}$ & 5 & $8.51 * * *$ & 7.81 \\
\hline
\end{tabular}

Statistically significant: $* * *$ at $\mathrm{p}<0.001, * *$ at $\mathrm{p}<0.05$, ns: no significant the optimal shadow of cereals and surface cover by crop residues. The higher ratio of total crumbs was usually found at the treatments where cover ratio reached at least $20 \%$ after sowing (at T, ST, DD), indicating the beneficial effect of the surface cover. The average total crumb ratio in the ploughed soil was significantly lower (by $9 \%$ ) related to the ploughless treatments. Finally, the ratio of total crumb percentage in the given eight years decreased in the order: $\mathrm{T}=\mathrm{ST}>\mathrm{DD}=\mathrm{L}>\mathrm{D}>\mathrm{P}$.

The calculation by rank correlation confirmed a significant $(\mathrm{p}<0.05)$ probable coherence between ratio of total and the large crumbs for rainy year $(\mathrm{r}=0.91>0.81$ at a $p<0.05$ level of significance). The coherence was found to be moderate in dry and average years.

The ratio of large soil crumb showed significant differences between tillage treatments $(p<0.05$; Fig. 2, Tables 2-3). The ratio of large crumbs reached or exceeded $40 \%$ at the T, ST and DD treatments in several years. This result is consistent with those of Kalmár et al. [5], who reported that increasing surface cover ratio significantly increased the large crumb formation.

Four of the six treatments are graphically presented by linear regression analysis (Fig. 2). According to Sváb [22], the correlation coefficient shows moderate coherence at the $\mathrm{P}$ and $\mathrm{D}$ treatments, and a looser relationship at the ST and DD treatments. Since the experiment was set on the physically degraded soil [24], the use of soil conservation tillage was expected to improve crumb formation. Birkás et al. [25] stated that the reduction of the crumbs in wet season is lower than in the dry season, but the chance of improvement is fairly moderate during average season. This assumption is harmonised to the findings of Gyuricza et al. [15], who found poor crumb formation in a Chernozem soil when the dry season replaced a rainy period. Birkás et al. [26] stated that the decrease of large crumbs in ploughed and disk-tilled soils may be permanent and suggested revaluating traditional tillage interventions. Beyond this, Tuo et al. [27] indicated the improvement 


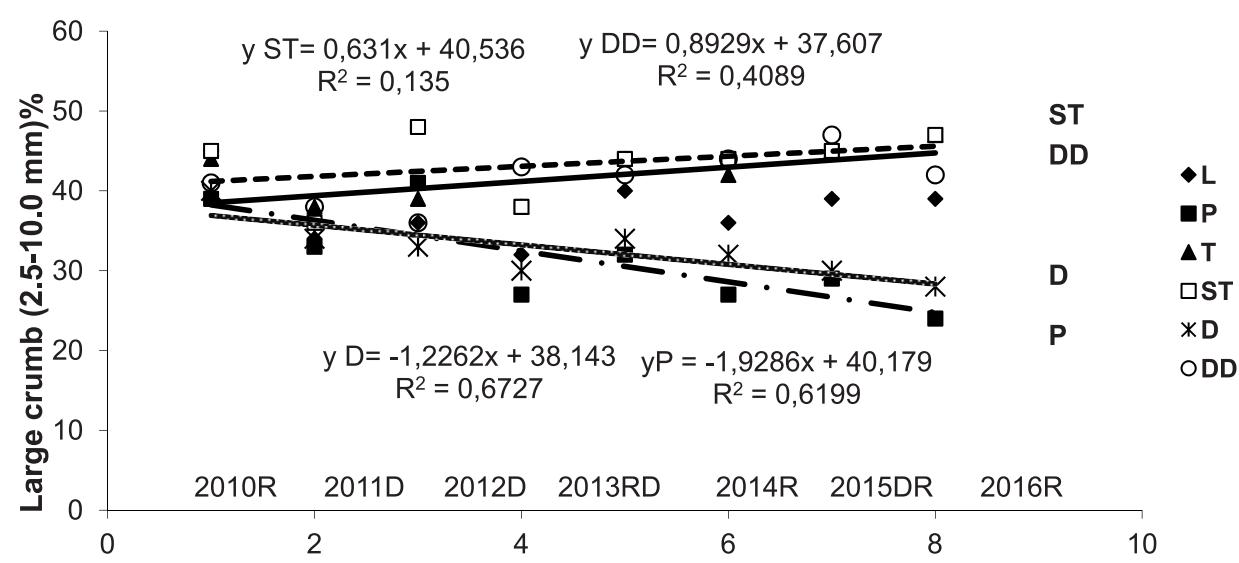

Fig. 2. Ratio of large crumbs $(2.5-10 \mathrm{~mm})$ at four tillage treatments and in variable seasons (R: rainy; D: dry; RD: rainy and dry; DR: dry and rainy); L: loosening; P: ploughing; T, ST: tine tillage - deeper, and shallower; D: disk tillage; DD: direct drilling.

of soil structure by farmyard manure incorporation into soil.

\section{Soil Moisture Range for Workability}

When applying a cultivation method, the quality of the intervention is highly influenced by soil moisture. The lower limit of cultivation (WL) means a dry state and the upper limit (WH) shows a nearly wet condition. It is commonly known that loosening is more effective at dry (OS), and ploughing at moistened (OP) soil conditions. Moisture optimum (OT) means a soil state that produces the slightest damage during cultivation. This soil moisture range of the Chernozem soil at the region of Hatvan is close to the recommended moisture of soil for ploughing (OP, Fig. 3). Likewise, the lower limit of cultivation (WL) and the recommended moisture content for soil loosening (OS) are almost the same.
In the last three years, the autumnal season was wet, which justified the inclusion of the HT to the moisture variants. As shown in Fig. 3 and Table 3, there were significant differences between soil moisture ranges for the workability of different tillage operations $(p<0.05)$.

Among the authors, Dexter and Bird have attributed great importance to research soil moisture ranges for workability [28]. Obour et al. [29] stated that knowledge of soil workability is important for scheduling tillage operations and for reducing the risk of tillage-induced structural degradation of soils. Obour et al. [29] outlined the fact that reliable evaluation of soil workability implies a distinctive definition of the critical water content (wet and dry limits) for tillage. Obour et al. [30], on the basis of long-term experiments, found a strong positive linear increase in the range of water contents for tillage with increasing contents of soil organic carbon.

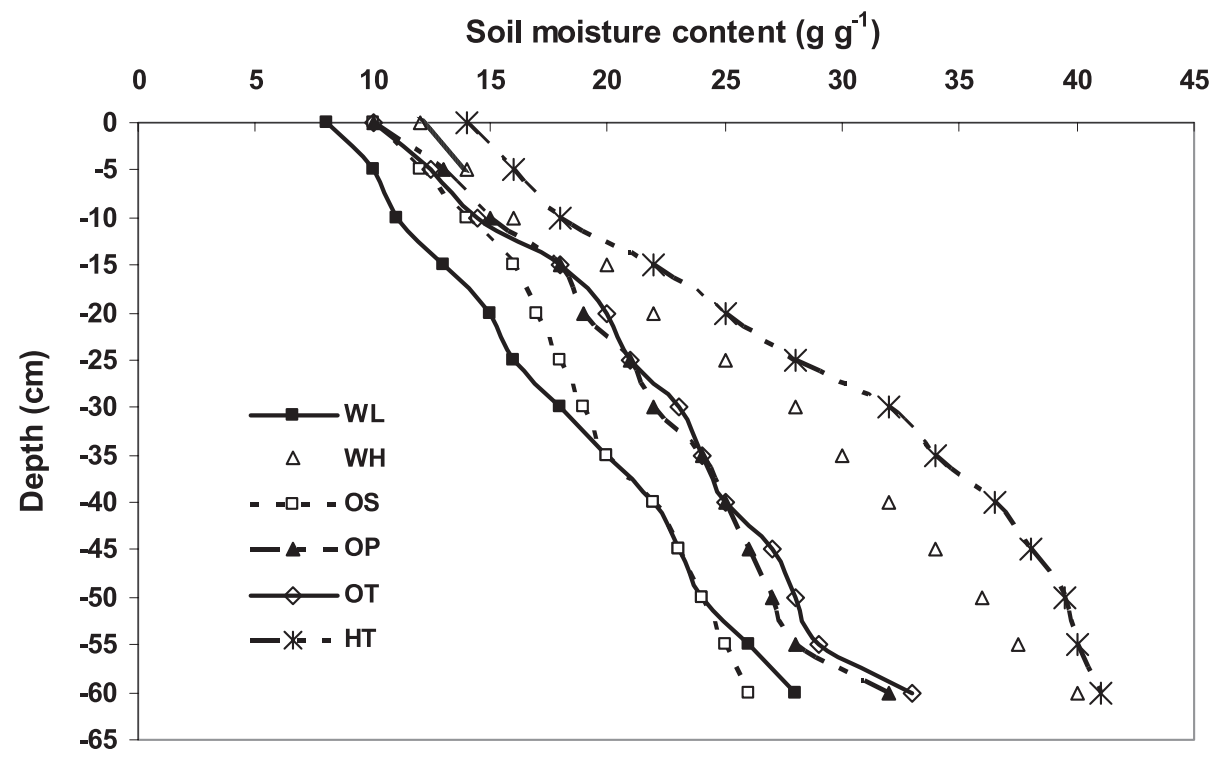

Fig. 3. Soil moisture contents for different workability of soil (WL: workability, lower water level; WH: workability, highest water level; OS: optimal for subsoiling; OP: optimal for ploughing; OT: optimal level for tillage; HT: highest water level for tine tillage). 


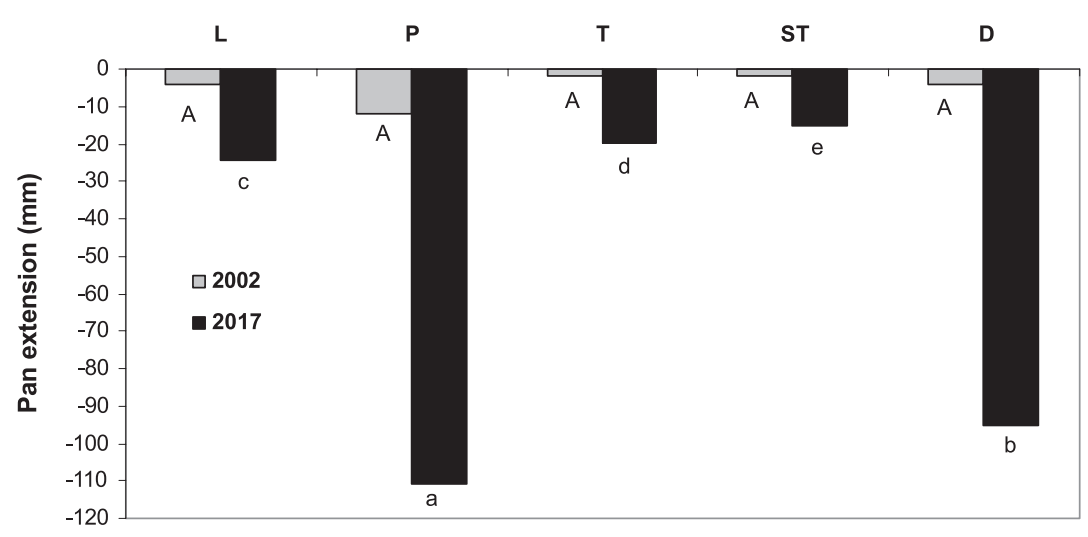

Fig. 4. Tillage pan occurrence and extension in the first and 16th years (L: loosening, P: ploughing, T, ST: tine tillage, D: disk tillage); different letters indicate statistical difference $(\mathrm{p}<0.05)$ between treatments during 2002 (uppercase letters) and 2017 (lowercase letters).

These results draw attention to the short- and the long-term tasks. A tillage operation in a given moment is to adapt to the soil moisture content for decreased tillage-induced damage. Improving soil workability requires the continuous conservation of the factors, especially the organic matter content.

\section{Extension of Tillage Pan Compaction}

Tillage-induced compaction is one of the negative results of the soil disturbance by cultivation tools [31]. Birkás et al. $[8,11]$ noted the use of a plough and disk support pan formation. The plough and the disk pan compaction have occurred in soil since the beginning of the experiment (Fig. 4). At the beginning of the experiment, the extension of the plough pan was quite slight $(10-13 \mathrm{~mm})$ and similarly narrow $(3.5 \mathrm{~mm})$, below the edge of the disk tillage [32]. During 2002 no significant differences between tillage treatments were found. In 2017, the average thickness of the plough pan reached $111 \mathrm{~mm}$, and the disk pan reached $95 \mathrm{~mm}$ on average. A relatively narrow pressed layer was observed at the ploughless treatments (L, T, ST). Statistical analysis proved that tillage treatments had a significant effect $(p<0.05)$ on the extension of pan compaction
(Table 2). The extent of the compacted layer was due to the repetition of the same cultivation at the same depth on wet soil. Although the pressing effect of the ploughless treatments (L, T, ST) was also observed, they proved to be smaller and more easily remedied damage. Assessing the plough pans, Đekemati et al. [14] outlined how the same plough or disc were unsuitable for loosening the compact layer that had previously formed.

Research of soil compaction reflects real findings [33], and the methods for preventing or remedying soil compaction have been published by several regional authors [8, 9, 13, 32, 34]. Gelybó et al. [35] stressed that climate becoming more extreme focuses more attention on methods of prevention and mitigation of tillageinduced compaction.

\section{Crust Formation}

The original reason for the crust is the high amount of dusts formed by multi-traffic cultivation on the surface. Dust forms to silty film after heavy rains and follows rapid drying that becomes a hard crust on the soil surface. The extent of the crusted area in three types of seasons is shown in Fig. 5. The tillage treatments had

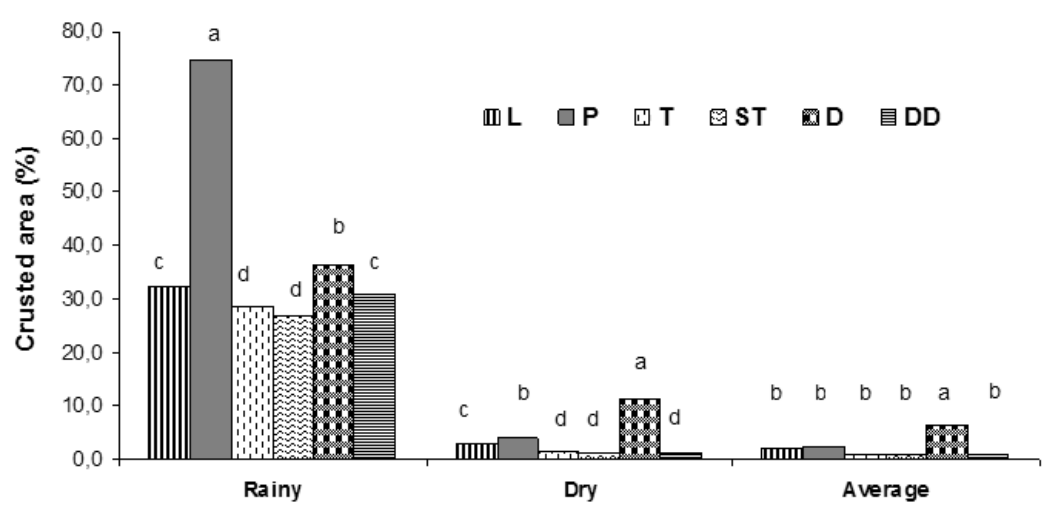

Fig. 5. Ratio of crusted area in three different seasons and at tillage treatments (L: loosening, P: ploughing, T, ST: tine tillage, D: disk tillage, DD: direct drilling); means followed by the same letters above the column are not significantly different as statistically). 
a significant effect on the crusted area in three types of seasons $(p<0.05$, Table 2$)$. The silt and then the crust formation became high on ploughed (P) and disk-tilled (D) treatments, mostly due to inadequate surface cover (Table 1). The least crusted area detected on the surface of the tine tilled and direct-drilled treatments. It may be noted that the crusting occurred in the rows of the widerow crops during the seasons, and in the rows of winter cereals after wintering. According to Gallardo-Carrera et al. [10], a structural crust is formed from microparticles produced by the breakdown of soil surface aggregates. They outlined that these particles are reorganised into a denser and more continuous structure by clogging pore systems in the soil. Badorreck et al. [36] emphasized that the reason for silting and crusting on the soil surface are negative processes and that both impede the movement of moisture, air and heat. In their experiment, the crusting of the surface is mainly observed in the period of sowing. However, GallardoCarrera et al. [10] found that residues or mulches left on the soil surface prevented the formation of the crust by dissipating the energy of the raindrops before they hit the soil surface. It has to be said that the clean surface at present climatic extremes will become the real risk factor of crop production.

\section{Number of Earthworms}

Earthworm activity may be an indicator of the level of the soil biological state. The number of earthworms was counted to the depth of $0-200 \mathrm{~mm}$. Results are presented in Fig. 6. The tillage treatments had a significant effect on the number of earthworms in three different seasons $(\mathrm{p}<0.05$, Table 3$)$. Most of the earthworms were found in a moderate rainy season (2014), and when the dry season was replaced by a moderated rainy season (2015). The crops grown in the plots had slight influence on the number of earthworms. The undisturbed soil (direct drilling, DD) and the moderately disturbed soil (ST) proved to be favourable, and the ploughed soil has proven to be an unfavourable habitat for earthworms in the long-term period. There was no significant effect of disk-tilled (D) soil state on the number of earthworms. A greater fluctuation of the earthworm number was found at the $\mathrm{T}$ and $\mathrm{L}$ treatments due to the smaller proportion of surface cover. In such cases, the dry soil status $(2011,2012)$ or the intense rainy season may be a desertification habitat. Presumably, dry soil conditions $(2011,2012)$ or the intense rainy season (2010) may lead to the deterioration of the earthworm habitat. The literature data $[12,37]$ confirms the decreasing effect of ploughing on the earthworm number and activity. Birkás et al. [26] assumed that the unfavourable effect of ploughing on earthworm habitat may occur by the poor distribution of stubble residues in the disturbed layer. According to Birkás et al. [11], a tillage focusing on preserving soil moisture, structure, and organic materials, covering the surface in the critical periods and creating adequate soil loosening are fundamental pre-requisites for making the soil a favourable habitat for earthworms.

\section{Soil Condition Ranking}

Ranking the soil tillage treatments was made by evaluating the soil quality factors studied in the research. The total crumb ratio $(0.25-10 \mathrm{~mm}$ in diameter) in the given eight years decreased in the order: $\mathrm{T}=\mathrm{ST}>\mathrm{DD}=\mathrm{L}>\mathrm{D}>\mathrm{P}$. However, the ratio of large crumbs $(2.5-10.0 \mathrm{~mm}$ in diameter) increased in the order: $\mathrm{P}<\mathrm{D}<\mathrm{L}<\mathrm{T}<\mathrm{DD}<\mathrm{ST}$. Assessing the soil moisture range for workability stated the importance of the soil-preserving disturbance with regards to the extreme climate phenomena. The rank was as follows (decreasing in order): $\mathrm{ST}>\mathrm{DD}>\mathrm{T}>\mathrm{L}>\mathrm{D}>\mathrm{P}$. Avoiding pan compaction is the most important task of tillage tools that press the crumbs with moderate damage. The ranking order was in a downward tendency: $\mathrm{ST}>\mathrm{L}>\mathrm{T}>\mathrm{D}>\mathrm{P}$. Rank of the tillage treatments avoiding the crust formation were as follows: $\mathrm{ST}<\mathrm{T}<\mathrm{DD}<\mathrm{L}<\mathrm{D}<\mathrm{P}$, that is surface cover had higher importance during these extreme years. Considering the earthworm

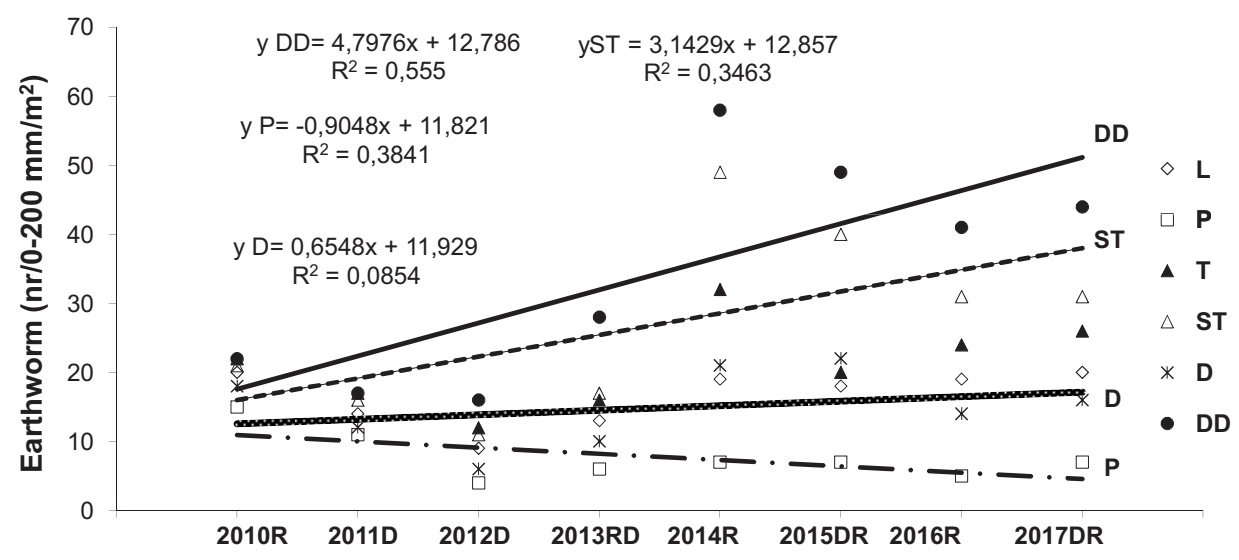

Fig. 6. Earthworm numbers (at a depth of $0-200 \mathrm{~mm} / \mathrm{m}^{2}$ ) at four tillage treatments and in variable seasons (R: rainy, D: dry, RD: rainy and dry, DR: dry and rainy; L: loosening, P: ploughing; T, ST: tine tillage; D: disk tillage; DD: direct drilling). 
activity, the order of the tillage treatments, in downward tendency, was: $\mathrm{DD}>\mathrm{ST}>\mathrm{T}>\mathrm{L}>\mathrm{D}>\mathrm{P}$. The final order with the ranks of tillage treatments and the evaluation points was the following from the best to the worst: ST (29) $>$ DD (22) $>$ T (20) $>$ L (15) $>$ D (6) $>$ P (0).

The rank of the soil tillage treatments by six soilquality factors may help to draft the prevention and alleviation processes considering the unpredictable climate. The benefits of mulch tillage (in the given study at the T, ST, L) are discussed in detail by $[4,5,38]$, and are consistent with earlier publications. The advantages and disadvantages of the DD are known from the relevant publications [e.g., 1, 39]. Kende et al. [24] outlined how the benefits of minimal soil disturbance can be expected after 6-8 years of soil transition. Research conducted by Birkás et al. [26] called attention to maintaining or creating a deeply loosened state alleviating the settling effect of the intense rainfall. Similarly, He et al. [40] reported, that subsoiling and straw cover soil management practices appear to be more sustainable than conventional methods that utilize crop residue removal. The appreciation of the disc tillage is variable, however the disadvantage of disk compaction damage was sufficiently clarified [41, 42]. Study results indicate that soil conditions under ploughed soil has been classified as an operation endangering the soil quality as noted elsewhere [43], although some of the authors found positive impacts on some crop production phases [44].

\section{Conclusions}

Six factors were evaluated at six tillage treatments having different impacts on soil condition. The ratio of the total and the large crumbs reflected the importance applying soil structure preserving tillage intervention. Investigation of the soil moisture range for workability stated finding adaptable solutions both in dry and wet soil conditions. The loosening and the two types of tine tillage are found to be effective in avoiding compacted tillage pan occurrence and extension in wet soils due to less damage of tools at the edge of tillage. Residue cover at tine and direct drilling treatments proved to be positive in reducing the crust formation and providing favourable earthworm habitat. The very last rank of long-term tillage management on soil quality was as follows: tine (shallower) $>$ direct drilling $>$ tine (deeper) $>$ loosening $>$ disk tillage $>$ ploughing. Such results are crucial for decision-making in order to select the most adaptable tillage system adapting to the mitigation of agricultural activities and climate hazards.

\section{Acknowledgements}

This project was implemented with support from the Ministry of Human Resources of Hungary, project No. VKSZ-12-1-2013-0034 Agrárklima 2.
We express our great appreciation to the EFOP-3.6.3VEKOP-16-2017-00008 project. The project is cofinanced by the European Union and the European Social Fund.

\section{Conflicts of Interest}

The authors declare no conflicts of interest.

\section{References}

1. SCHERTZ D.L. Conservation tillage: An analysis of acreage projections in the United States. J. Soil and Water Conservation, 43, 256, 1988.

2. BIRKÁS M., KISIĆ I. MESIĆ M., JUG D., KENDE Z. Climate induced soil deterioration and methods for mitigation. Agriculturae Conspectus Scientificus, 80 (1), 17, 2015.

3. NIMMO J.R. Aggregation: Physical aspects. In: Hillel, D., ed., Encyclopedia of Soils in the Environment: London, Academic Press, 1, 2004.

4. MORRIS N.L., MILLER P.C.H, ORSON J.H., FROUDWILLIAMS, R.J. The adoption of non-inversion tillage systems in the United Kingdom and the agronomic impact on soil, crops and the environment - A review. Soil \&Tillage Res., 108 (1-2), 1, 2010.

5. KALMÁR T., BOTTLIK L., KISIĆ I., GYURICZA C., BIRKÁS M. Soil protecting effect of the surface cover in extreme summer periods. Plant, Soil and Environ., 59, 404, 2013.

6. JUG D., JUG I., BROZOVIĆ B., VUKADINOVIĆ V., STIPEŠEVIĆ B., ĐURĐEVIĆ B. The role of conservation agriculture in mitigation and adaptation to climate change. Poljoprivreda/Agriculture, 24 (1), 35, 2018.

7. VÁRALLYAY G. Soil moisture regime as an important factor for soil fertility. Növénytermelés, 62 (Suppl.), 307, 2013.

8. BIRKÁS M., KISIĆ I., BOTTLIK L., JOLÁNKAI M., MESIĆ M., KALMÁR T. Subsoil compaction as a climate damage indicator. Agriculturae Conspectus Scientificus, 74 (2), 1, 2009.

9. BOGUNOVIĆ I., KISIĆ I., JURIŠIĆ A. Soil compaction under different tillage systems on Stagnic Luvisols. Agriculturae Conspectus Scientificus, 79 (1), 59, 2014.

10. GALLARDO-CARRERA A., LÉONARD J., DUVAL Y., DÜRR C. Effects of seedbed structure and water content at sowing on the development of soil surface crusting under rainfall. Soil \& Tillage Res., 95, 207, 2007.

11. BIRKÁS M., JOLÁNKAI M., GYURICZA C., PERCZE A. Tillage effects on compaction, earthworms and other soil quality indicators in Hungary. Soil \& Tillage Res., 78 (2), 185, 2004.

12. KLADIVKO E.J. NEELA M.A., WEESIES G. Earthworm populations and species distributions under no-till and conventional tillage in Indiana and Illinois. Soil Biology and Biochemistry, 29 (3-4), 613, 1997.

13. BAS̆IĆ F. Soils in Croatia. World Soils Book Series. Springer, p. 179, 2013.

14. ĐEKEMATI I., RADICS Z., KENDE Z., BIRKÁS M. Soil state assessment in Croatia and in Hungary Similarities and differences. Növénytermelés, 65 (Suppl.), 139, 2016. 
15. GYURICZA C., SMUTNÝ V, PERCZE A., PÓSA B., BIRKÁS M. Soil condition threats in two seasons of extreme weather conditions. Plant, Soil and Environ., 61, 151, 2015.

16. IUSS Working Group WRB. World Reference Base for Soil Resources 2014, update 2015. International Soil Classification System for Naming Soils and Creating Legends for Soil Maps. World Soil Resources Reports No. 106. FAO, Rome, 2015.

17. TÓTH E., GELYBÓ GY., DENCSÖ M., KÁSA I., BIRKÁS M., HOREL Á. Soil $\mathrm{CO}_{2}$ Emissions in a Longterm Tillage Treatment Experiment. In: Munoz M., Zornoza R. (ed.) Soil Management and Climate Change: Effects on Organic Carbon, Nitrogen Dynamics, and Greenhouse Gas Emissions. Elsevier, Academic press, 293, 2017.

18. FILEP G. Physical characters of soil. In: Stefanovits, P., Filep, Gy., Füleky, Gy. (eds.): Talajtan (Soil Science). Mezőgazda Kiadó, Budapest, 131, 1999 [In Hungarian].

19. CSORBA S., FARKAS C., BIRKÁS M. Dual porosity water retention curves for characterizing the effect of tillage. Agrokémia és Talajtan, 60 335, 2011 [In Hungarian].

20. BIRKÁS M., JUG D., KENDE Z., KISIĆ I., SZEMÖK A. Soil tillage response to the climate threats - Revaluation of the classic theories. Agriculturae Conspectus Scientificus, 83 (1), 1, 2018.

21. SALLAWAY M.M., YULE D.F., MAYER D., BURGER P.W. Effects of surface management on the hydrology of a Vertisol in semi-arid Australia. Soil \& Tillage Res., 15, 227, 1990.

22. SVÁB J. Biometrical Methods in Research Work ( $3^{\text {rd }}$ Ed.). Mezőgazdasági Kiadó, Budapest, 1981 [in Hungarian].

23. STEFANOVITS P. Soil conservation today. Talajvédelem, 2 (1-2), 24, 1994.

24. KENDE Z., SALLAI A., KASSAI K., MIKÓ P., PERCZE A., BIRKÁS M. The effects of tillage induced soil disturbance on weed infestation of winter wheat. Pol. J. Environ. Stud., 26 (3), 1131, 2017.

25. BIRKÁS M, ĐEKEMATI I, KENDE Z, PÓSA B. Review of soil tillage history and new challenges in Hungary. Hung. Geo. Bull., 66 (1), 55, 2017.

26. BIRKÁS M., BOGUNOVIĆ I., ĐEKEMATI I., KISIĆ I., RADICS Z. Adaptable tillage - is that a solution for the present climate situation? In: Jug D., Brozović B. (eds.) Proceedings and Abstracts, $11^{\text {th }}$ international/professional conference agriculture in nature and environment protection. 28-30 May, 2018, Vukovar. Glas Slavonije d.d., Osijek, 10, 2018.

27. TUO D.F., XU M.X., LI Q., LIU S. Soil aggregate stability and associated structure affected by long-term fertilization for a loessial soil on the Loess Plateau of China. Pol. J. Environ. Stud., 26. (2) 827, 2017

28. DEXTER A.R., BIRD N.R.A. Methods for predicting the optimum and the range of soil water contents for tillage based on the water retention curve. Soil \& Tillage Res., 57 203, 2001.

29. OBOUR P.B., LAMANDÉ M., EDWARDS G., SØRENSEN S.G., MUNKHOLM N.J. Predicting soil workability and fragmentation in tillage: a review. Soil Use and Management, 33 (2), 288, 2017.
30. OBOUR P.B., JENSEN J.L., LAMANDÉ M., WATTS C. W., MUNKHOLM N.J. Soil organic matter widens the range of water contents for tillage. Soil \& Tillage Res., 182 57, 2018.

31. BOGUNOVIC I., PEREIRA P., KISIC I., SAJKO K., SRAKA M. Tillage management impacts on soil compaction, erosion and crop yield in Stagnosols (Croatia). Catena, 160, 376, 2018

32. BIRKÁS M. Long-term experiments aimed at improving tillage practices. Acta Agr. Hung., 58 (1) 75, 2010.

33. JONES R.J.A, SPOOR G., THOMASSON A.J. Vulnerability of subsoils in Europe to compaction: a preliminary analysis. Soil \& Tillage Res., 73, 131, 2003.

34. BOGUNOVIC I., KISIC I. Compaction of clay loam soil in Pannonian Region of Croatia under different tillage systems. J. Agr. Science and Technology, 19 (2), 475, 2017

35. GELYBÓ G., TÓTH E., FARKAS C., HOREL Á., KÁSA I., BAKACSI Z. Potential impacts of climate change on soil properties. Agrochemistry and Soil Science, 67 (1), 121, 2018.

36. BADORRECK A., GERKE H.H., HÜTTL R. F. Morphology of physical soil crusts and infiltration patterns in an artificial catchment. Soil \& Tillage Res., 129 (1), 2013.

37. BRIONES M.J.I., SCHMIDT O. Conventional tillage decreases the abundance and biomass of earthworms and alters their community structure in a global meta-analysis. Global Change Biology, 23 4396, 2017.

38. ZANIEWICZ-BAJKOWSKA A., FRANCZUK J, KOSTERNA E. Direct and secondary effects of soil mulching with straw on fresh mass and number of weeds, vegetable yield. Pol. J. Environ. Stud., 18, 1185, 2009.

39. SOANE, B.D., BALL, B.C., ARVIDSSON, J., BASC, G., MOENO F., ROGER-ESTRADE J. No-till in northern, western and south-western Europe: A review of problems and opportunities for crop production and the environment. Soil \& Till. Res., 118, 66, 2012.

40. HE J., LI H.W., WANG X.Y., MCHUGH A.D., LI W.Y., GAO H.W., KUHN N.J. The adoption of annual subsoiling as conservation tillage in dryland maize and wheat cultivation in northern China. Soil \& Tillage Res., 94 (2), 493, 2007.

41. BIRKÁS M., SZALAI T., GYURICZA C., GECSE M., BORDÁS K. Effects of the disk tillage on soil condition, crop yield and weed infestation. Crop Production. 48 (1), 20, 2002.

42. CHEN Y., TESSIER S. Techniques to diagnose plow and disk pans. Can. Agr. Eng., 39 (2), 143, 1997.

43. DANG Y.P., MOODY P.W., BELL M.J., SEYMOUR N.P., DALAL R.C., FREEBAIRN D.M., WALKER S.M. Strategic tillage in no-till farming systems in Australia's northern grains-growing regions: II. Implications for agronomy, soil and environment. Soil \& Tillage Res., 152, 115, 2015.

44. GRUBER S., PEKRUN K., MÖHRING J., CLAUPEIN W. Long-term yield and weed response to conservation and stubble tillage in SW Germany. Soil \& Tillage Res., 121 (49) 2012. 